\title{
Investigative modelling of the flood bypass channel in Kuching, Sarawak, by assessing its impact on the inundations of Kuching-Batu Kawa-Bau Expressway
}

\author{
Darrien Yau Seng Mah ${ }^{\mathrm{a} *}$, Sai Hin Lai ${ }^{\mathrm{a}}$, Ron Aldrino@ Ron Buking Chan ${ }^{\mathrm{b}}$ and Frederik Josep Putuhena ${ }^{\mathrm{c}}$ \\ ${ }^{a}$ River Engineering and Urban Drainage Research Centre (REDAC), Universiti Sains Malaysia, Engineering Campus, \\ 14300 Nibong Tebal, Penang, Malaysia; ${ }^{b}$ Department of Civil Engineering (Highway \& Transportation), \\ Faculty of Engineering, Universiti Malaysia Sarawak, 94300 Kota Samarahan, Sarawak, Malaysia; ${ }^{c}$ Department of \\ Civil Engineering (Water \& Environment), Faculty of Engineering, Universiti Malaysia Sarawak, 94300 Kota Samarahan, \\ Sarawak, Malaysia
}

(Received 22 September 2009; final version received 16 January 2010; accepted 10 March 2010)

\begin{abstract}
Flood risks not only include loss of human lives and properties, but also the transportation and communication. One major road in Kuching, the Kuching-Batu Kawa-Bau Expressway is often flooded and interrupted by floodwaters from Sarawak River. The Sarawak State Government had announced to build a flood bypass channel in Sarawak River to mitigate flood under the Ninth Malaysian Plan. This paper is a study on the effects of the structure in the flooding of the mentioned road stretch. The January 2004 event which is locally known as a 100-year flood, was run through a developed river model incorporated with the bypass facilities. The model had indicated a reduction of $53 \%$ of flooded road. Similarly, modelling of 10 and 50-year design floods had predicted over $50 \%$ of reduction. The bypass channel was said to be able to alleviate the flooding on the major road stretch.
\end{abstract}

Keywords: decision making; floods and flood works; infrastructure; mathematical modelling; river engineering; roads and highways.

\section{Background}

Kuching is inundated frequently by floodwaters from the Sarawak River (see Figure 1). The most recent floods occurred in February 2003, January 2004, 8-11 January 2009 and 29 January 2009. These recurrent floods caused significant damage to properties and severely disrupted transport and communication. Roads between Kuching and inland areas had been cut off by the rising floodwaters.

One of the most severely affected roads was the Kuching-Batu Kawa-Bau Expressway (see Figure 2), that cut across Sarawak River by the Batu Kawa Bridge. The road is coded as Federal Route and is the backbone of the local road system. It connects Kuching to the rural town of Bau, and it is also part of the Pan Borneo Highway that connects to other major towns in the state. Major roads like this can rarely avoid crossing a body of water. Interaction of road and water could cause a degree of impact with each other (Furniss et al. 1997, 1998). The flooding conditions on stretches of road near the Batu Kawa Bridge are shown in Figure 3. The expenditure on road maintenance and repair would be a huge undertaking considering the frequent repetition of floods in the Batu Kawa area.

The Sarawak State Government planned a flood bypass channel only $8 \mathrm{~km}$ downstream of Batu Kawa Bridge, where floodwater would be diverted before entering the capital city. It is understandable the first priority was given to the city areas to protect the existing administration, commercial and business premises. However, areas on the outskirts such as Batu Kawa need to be protected as well regarding transportation and communication. Thus, this paper is prompted to investigate the effects of the flood bypass facilities on Batu Kawa.

\section{Flood bypass channel}

A flood bypass channel is a large man-made structure that is designed to convey excess water from a river in order to reduce the risk of flooding (Narrabri Shire Council 2007). In the past, river engineering works have often caused channel instability and adversely affected the river's conservation and amenity value (Hey 1990). Recent guidelines have advocated a shift away from more technical bypass designs to

\footnotetext{
*Corresponding author. Email: darrien.mah@gmail.com 


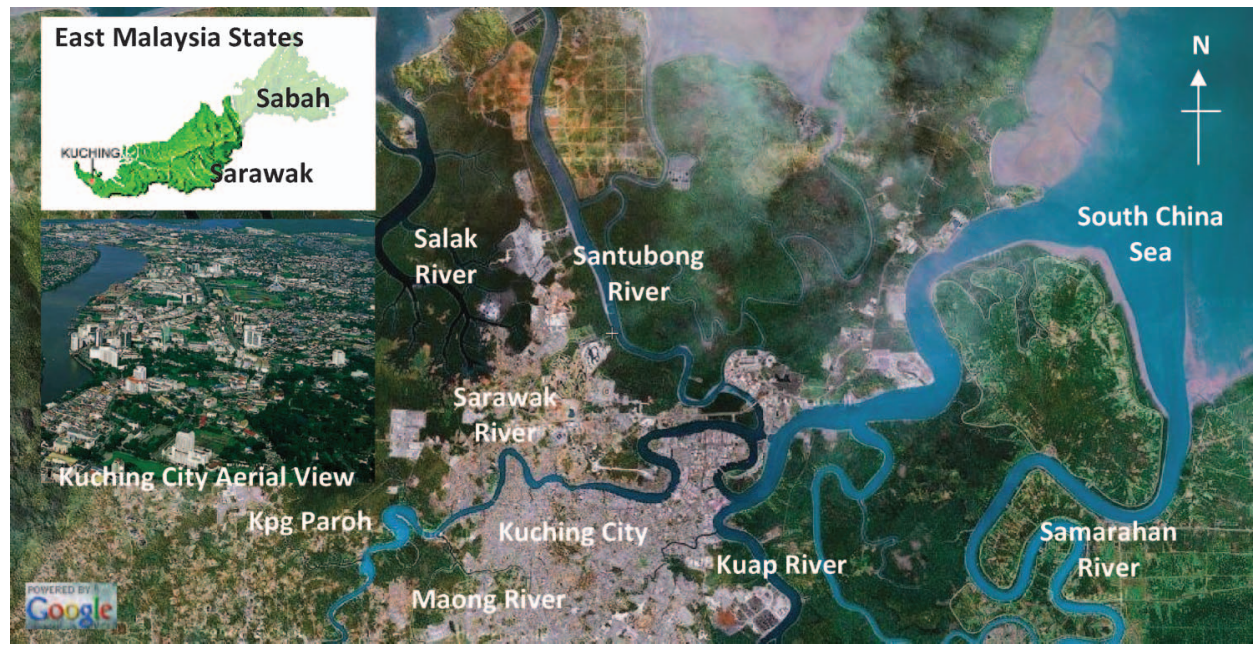

Figure 1. Locality of Kuching City (www.wikimapia.org).

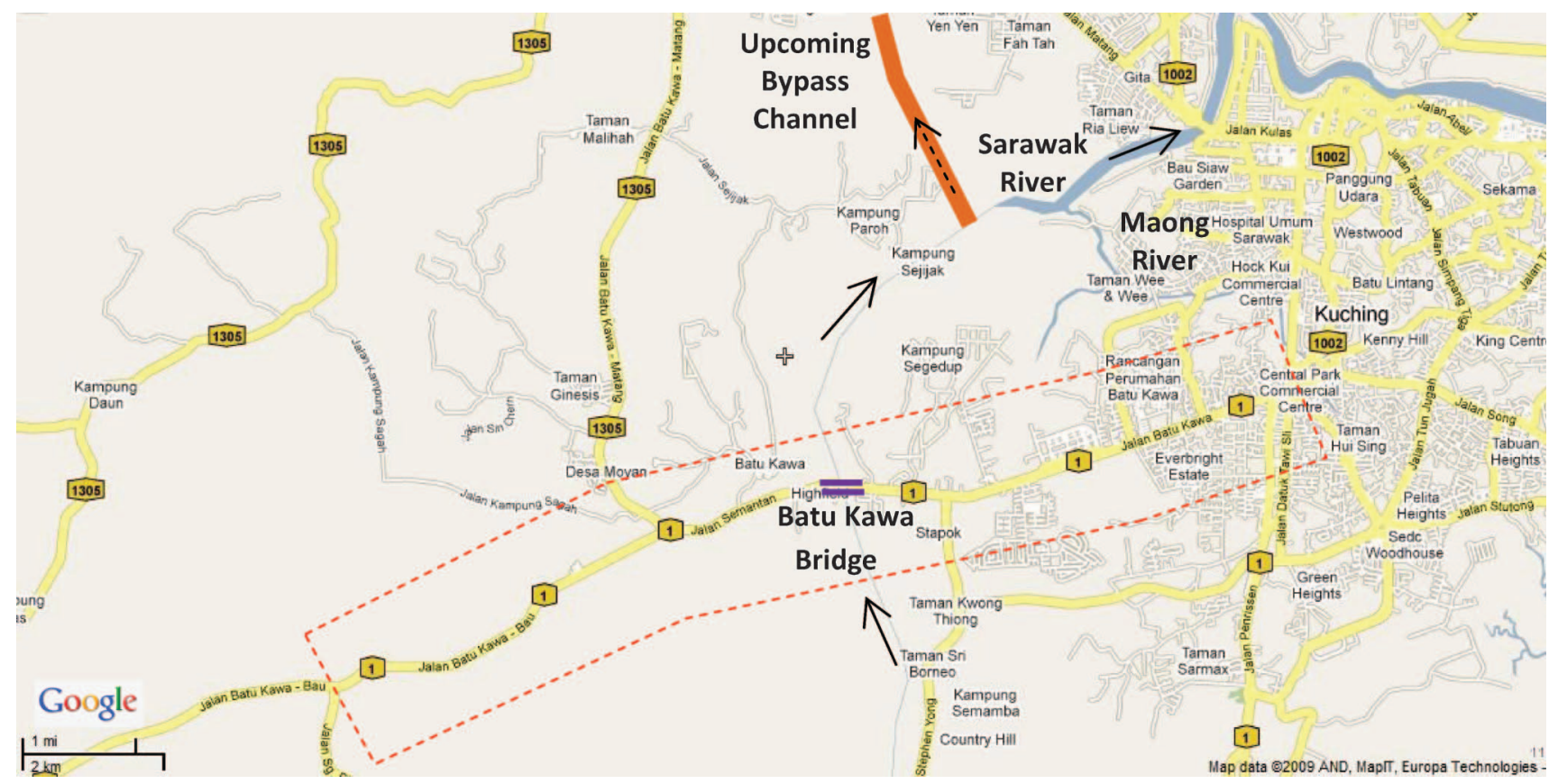

Figure 2. Major roads in Kuching (www.earth.google.com).

more nature-like passes. Santos et al. (2005) highlighted the use of these facilities for river restoration schemes. Sommer et al. (2001) gave the example of the famous Yolo flood bypass (California, US) that was successful from a flood control standpoint, and also compatible with fisheries, wetlands, wildlife and agriculture.

In the case of Sarawak River, the channel is designed to start from an 'oxbow', the natural river bend like a horseshoe shape near Kpg Paroh, and end at passing floodwaters into Salak River. A technical drawing of the structure imposed on a satellite image is shown in Figure 4. The channel will lie across a plain of peat wetlands. Salak River on the other hand is lined with mangrove swamp. According to the official technical report (Jurutera Jasa 2006), the flood bypass facilities would include $8 \mathrm{~km}$ long, $250 \mathrm{~m}$ base width, $10 \mathrm{~m}$ depth earth-dug (nature-like) rectangular 

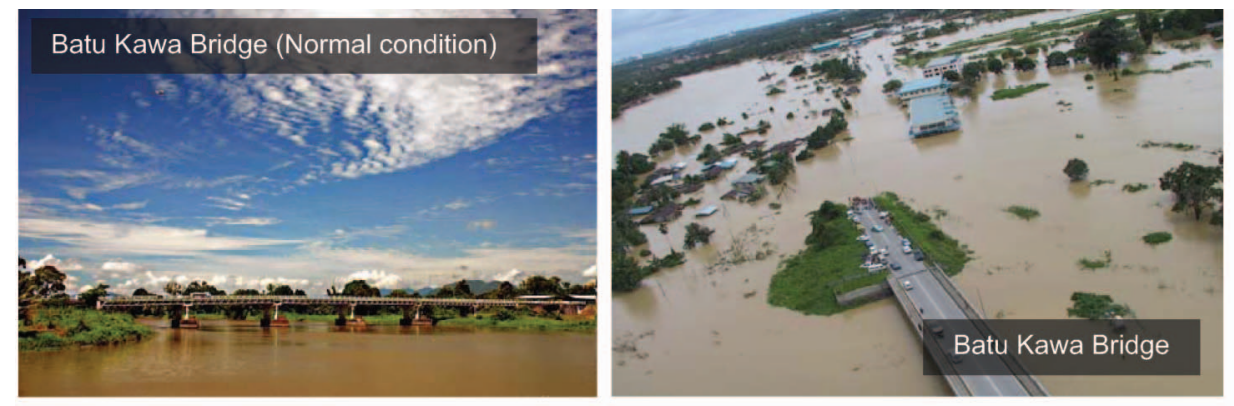

(a)
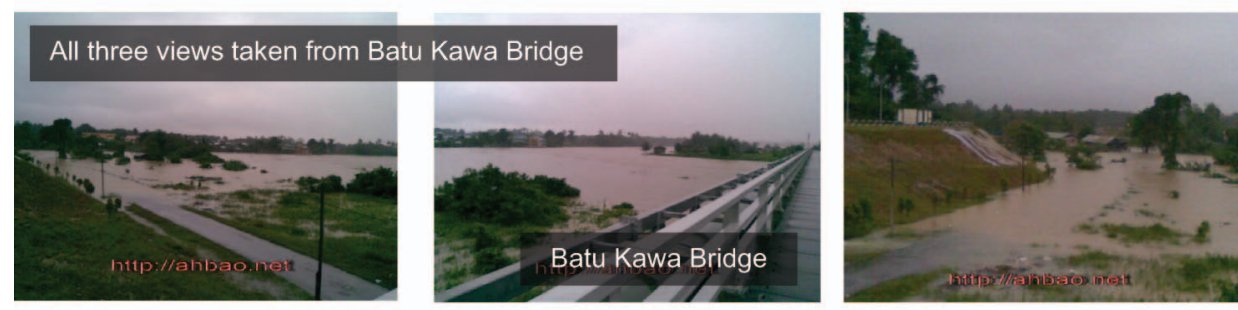

(b)

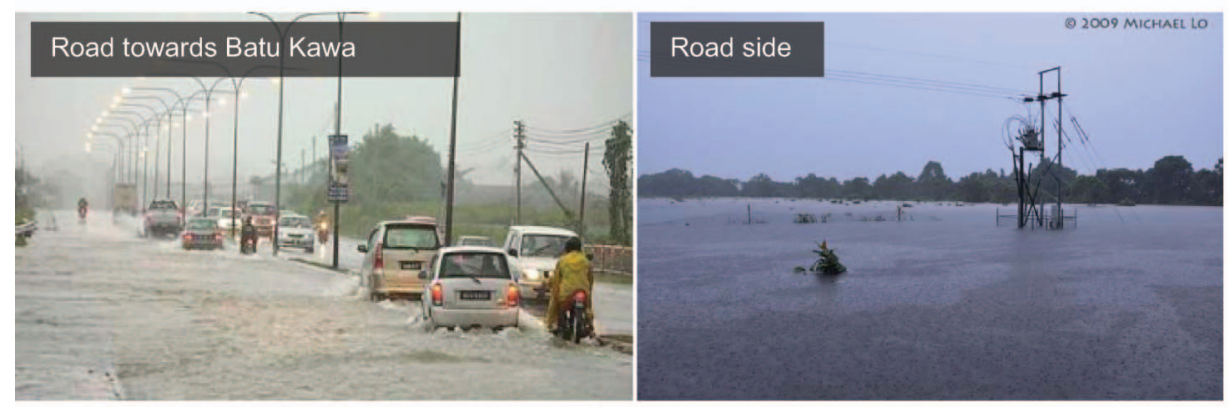

(c)

Figure 3. Flooding along Kuching-Batu Kawa-Bau Expressway during (a) January 2004 flood, (b) 8-11 January 2009 flood, and (c) 29 January 2009 flood.

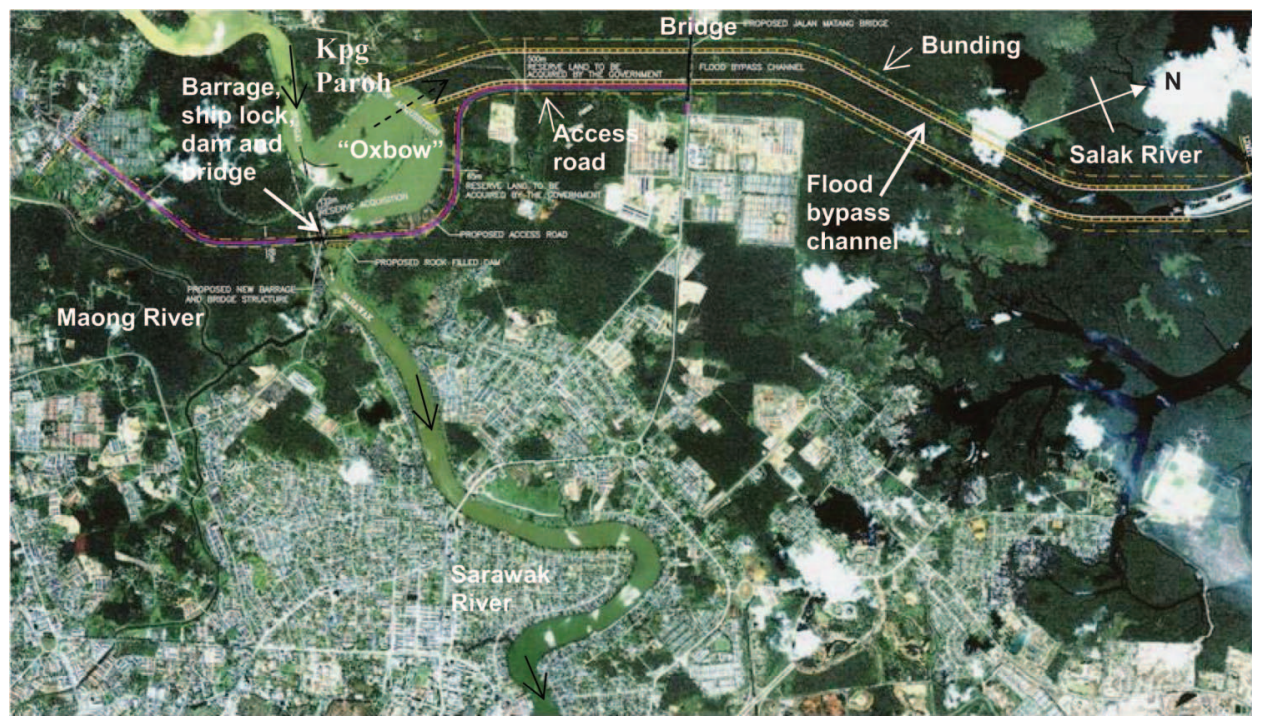

Figure 4. Flood bypass channel of Sarawak River (Jurutera Jasa 2006). 
channel. It would be sided with a $1 \mathrm{~m}$ high earth bund on reserve land of $125 \mathrm{~m}$ width at both sides. There will be two low-level bridges across the bypass channel, one with a tidal gate. The other one will be equipped with three bays of $25 \mathrm{~m}$ wide gated barrage with ship lock. Sarawak River will be closed with a rock-filled dam cum causeway, and this will divert the flow through the new barrage. The $11 \mathrm{~km}$ stretch access road will be tarsealed and function as a flood-proof bund. The structure is expected to be completed by 2015 , and therefore field data is absent at the current stage. However, a river hydraulic model would be able to give an insight into the dynamics of the water system.

\section{River model}

A Wallingford Software model, InfoWorks River Simulation (RS), was utilised for modelling Sarawak River. It is based on the Saint-Venant equations, which consist of the continuity equation, Equation (1), and the momentum equation, Equation (2). The solution of these equations defines the propagation of a flood wave with respect to distance along the channel and time. It computes flow depths and discharges, together with the proper boundary conditions, in mathematical terms, as non-linear hyperbolic partial differential equations.

$$
A \frac{\partial V}{\partial x}+V B \frac{\partial y}{\partial x}+B \frac{\partial y}{\partial t}=q
$$

where

$$
\begin{gathered}
A \frac{\partial V}{\partial x}=\text { prism storage } \\
V B \frac{\partial y}{\partial x}=\text { wedge storage } \\
B \frac{\partial y}{\partial t}=\text { rate of rise. }
\end{gathered}
$$

$A$, flow area; $B$, stream top width; $V$, velocity; $y$, river water level; $x$, distance along the channel; $t$, time; $q$, lateral flow into channel per unit length of channel.

$$
S_{f}=S_{o}-\frac{\partial y}{\partial x}-\frac{V}{g} \frac{\partial V}{\partial x}-\frac{1}{g} \frac{\partial V}{\partial t}
$$

where

$S_{f}$, friction slope (frictional forces); $S_{o}$, bed slope (gravitational effects); $G$, gravitational acceleration;

$$
\frac{\partial y}{\partial x}, \text { pressure differential; }
$$

$$
\frac{V}{g} \frac{\partial V}{\partial x}, \text { convective acceleration; }
$$

$$
\frac{1}{g} \frac{\partial V}{\partial t}, \text { local acceleration. }
$$

1-D models are tested repeatedly for performance in the literature. Horritt and Bates (2002) had reported that a 1-D model is performing equally as a 2D model, giving good predictions of floodplain inundated area on a $60 \mathrm{~km}$ reach of the River Severn, UK. Mark et al. (2004) had described the potential of a 1D model in urban flooding to visualise flood extent and impact in the form of GIS flood inundation maps. InfoWorks RS is a known one-dimensional model used for prediction of discharge and water level for a wide range of rivers, reservoirs, complex floodplains and narrow estuaries under both steady and unsteady conditions.

InfoWorks RS successfully modelled the problematic flooding in the Tabasco area of Mexico that features a combination of steep, bare mountain slopes and complex river-threaded plains in the south east of the country. In detail, the modelling involves a set of control structures with gates, embankments, drainage channels and flap gates, which allow excess flows to drain to designated floodplains (Wallingford Software 2008a). InfoWorks RS had been utilised to develop a flood map for Northern Ireland. The flood maps are considered suitable for a national assessment of fluvial and coastal flood extent and cover the majority of floodplains in Northern Ireland that formed a guide to assess the requirement for a more detailed investigation (Walling Software 2009). Another effort of InfoWorks RS was reported in the Malaysian state of Selangor which aims to model the impact of flooding caused by changes in the Selangor River catchment characteristics. The model provides explanations to the effects of varying runoff rates from sub-catchments (Wallingford Software 2006).

InfoWorks RS involves tight-coupling of GIS functionality and hydrodynamic flow simulation. This model relies profoundly on the accuracy of topographical data (Benito et al. 2004). The river basin elevation model was derived from a survey exercise done in the year 2000 in conjunction with the Sarawak River Mitigation Options Study (Jurutera Jasa 2003). In the absence of more advanced earth surface observation datasets, the available topographical data was used. These were adequate for one-dimensional (1D) modelling as previously proven by reports of Jenny et al. (2007) and Salim et al. (2009) in modelling Sarawak River systems. In the case of Sarawak River in its topographical conditions, the inundation occurs along or near the river and the inundation water does not diffuse widely in a 2D horizontal plane.

There are 24 hydrological stations along Sarawak River to record rainfall and water level data hourly. 
However, there is no direct measurement of flow data. Rating curves are available for the two upstream stations of Buan Bidi and Kpg Git that have been calibrated from time to time (Mah et al. 2007). With these hydrological data, a base river model simulating the existing conditions of Sarawak River was calibrated. As demonstrated in Figure 5, the matching of the recorded and modelled hydrographs during

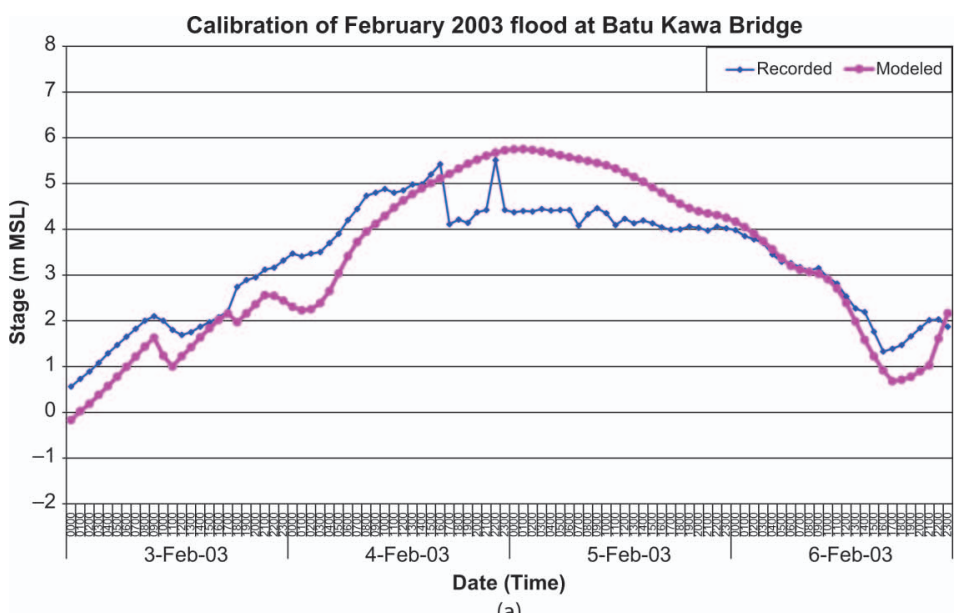

(a)

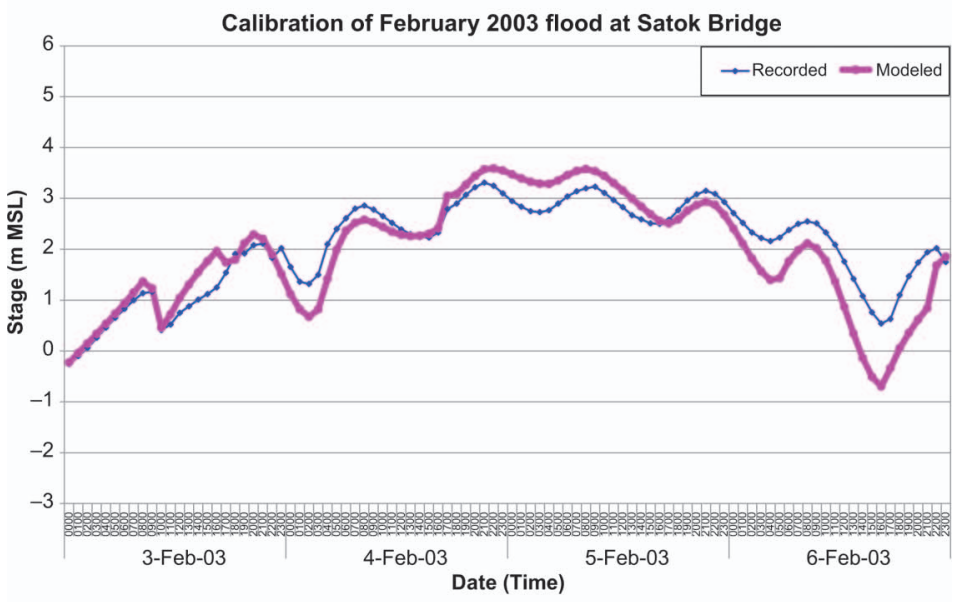

(b)

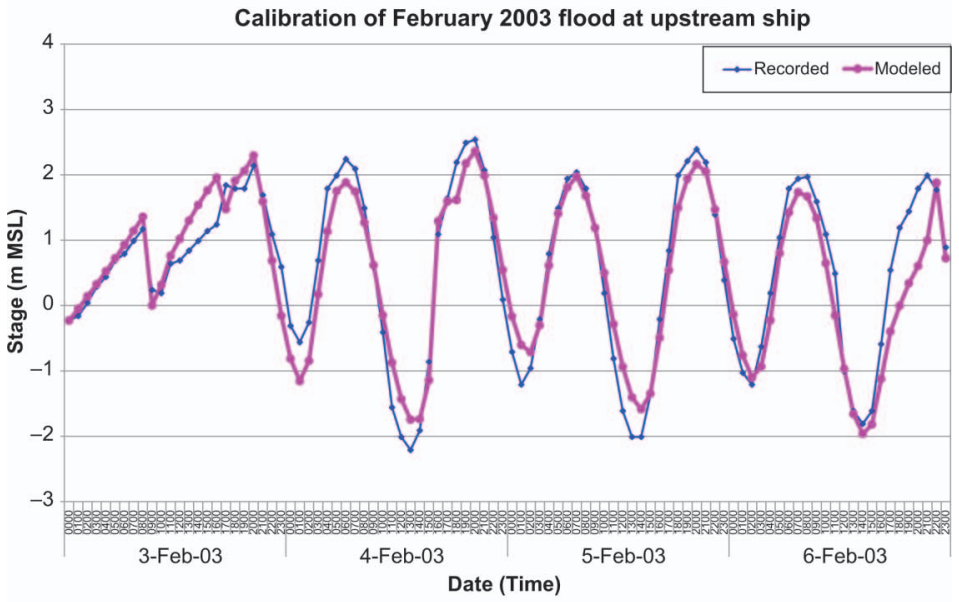

(c)

Figure 5. Model Calibration of February 2003 Flood Event at Locations (a) Batu Kawa Bridge, (b) Satok Bridge and (c) Ship Lock (at Muara Tebas). 
the February 2003 flood event is acceptable, with a correlation coefficient of over 0.80 . The calibrated model mimicked the real river behaviours by $80 \%$ of confident before the flood bypass structures were added to the network for investigation.

The flood bypass channel was modelled as a river channel extending from the 'oxbow' while the downstream end at Salak River was modelled as Stage-Time Boundary. The Stage-Time datasets were set at bank full water levels assuming that the channel would be at maximum conveying capacity during flood event. The assumption made here was that the whole of the floodwater would be diverted to Salak River, prohibiting any excess water entering the city by a barrage. The barrage was modelled as radial gates (Wallingford Software 2008b).

\section{Results and discussion}

The river model was used to simulate the January 2004 flood event, and subsequently 2, 10 and 50-year return period design floods. In order to model the January 2004 event, observed hourly water level data for 4 days (21-24 January) were fed to the model, which incorporated the peak flood levels. After 25 January missing data caused some serious gaps in the water level time series (DID 2004) and therefore were not used. The flood depths along the Sarawak River differ, reaching 3-5 $\mathrm{m}$ deep at some low-lying areas. In the Batu Kawa areas the flood depths modelled range from 0.1 to $2 \mathrm{~m}$. Batu Kawa on the left bank is lower in elevation than the right. However, the inundations of the road modelled are below $1 \mathrm{~m}$ deep.
The maximum flooding of Sarawak River for existing conditions is shown in Figure 6, while the maximum flooding with inclusion of flood bypass channel is shown in Figure 7. The insets in the two figures show a close up of the Batu Kawa areas, with the Kuching-Batu Kawa-Bau Expressway spanning the Sarawak River. Simulation of the January 2004 flood shows that Batu Kawa areas were flooded with the mentioned road submerged in great deal for more than $10 \mathrm{~km}$. The model also revealed that a repetition of an extreme flood event like January 2004, even though in a flood bypass, would still show flooding around Batu Kawa but with only $4.8 \mathrm{~km}$ of road affected.

Water level hydrographs of the January 2004 flood event with and without flood bypass along Sarawak River are presented in Figures 8 and 9. In the case of modelling existing river conditions, the simulated water levels were of the combination of 100-year flood flows coincided with the highest astronomical tides at $6.5 \mathrm{~m}$. Therefore the levels were noticeably high. Three locations were identified and plotted for comparison (see Figure 8), namely Pending, Kuala Maong and Batu Kawa (locations marked in Figure 6). It was shown that the tidal effects were significant until Batu Kawa. The model showed an estimate of peak flood flow up to $8000 \mathrm{~m}^{3} / \mathrm{s}$.

In the case of modelling flood bypass channel, the structure had divided the river into two stretches. In this paper, the authors named them the Lower and Upper Sarawak River. The Lower Sarawak River would be a total regulated river controlled by two barrages. The same 100-year flows and highest

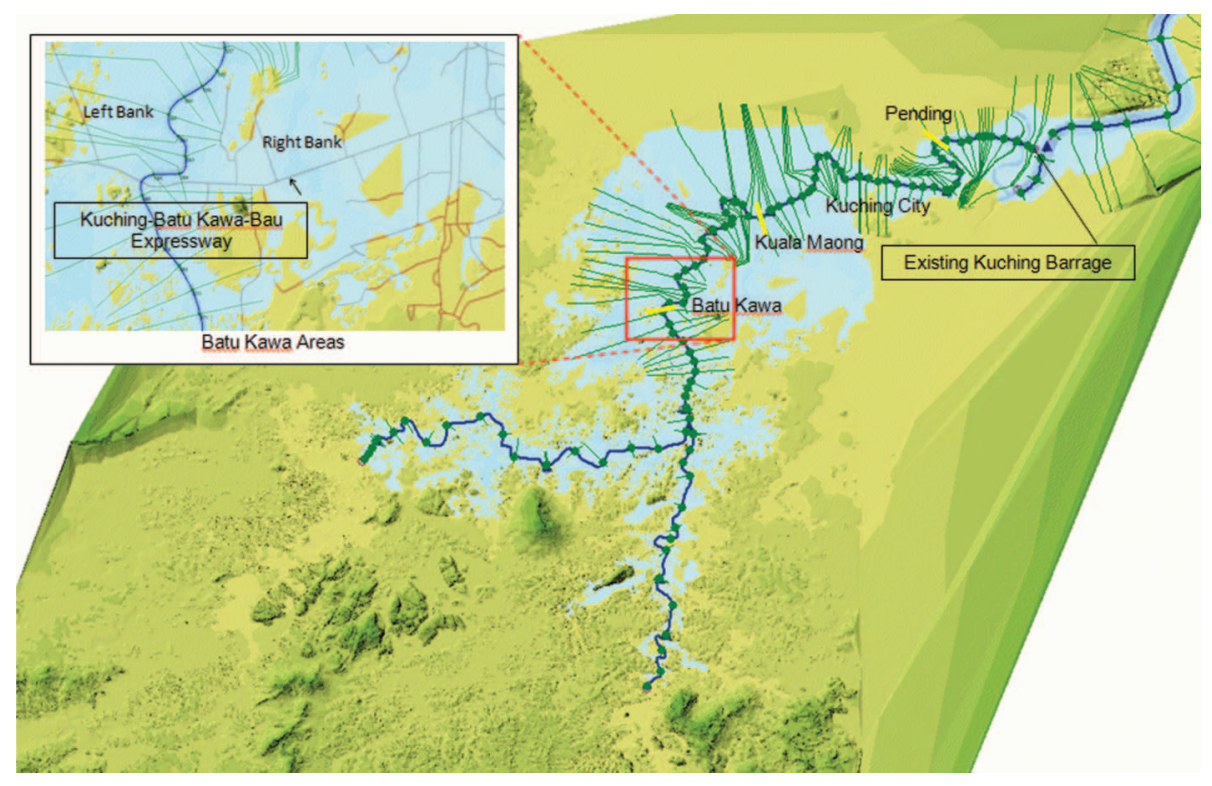

Figure 6. Simulation of January 2004 flood event without any measures. 


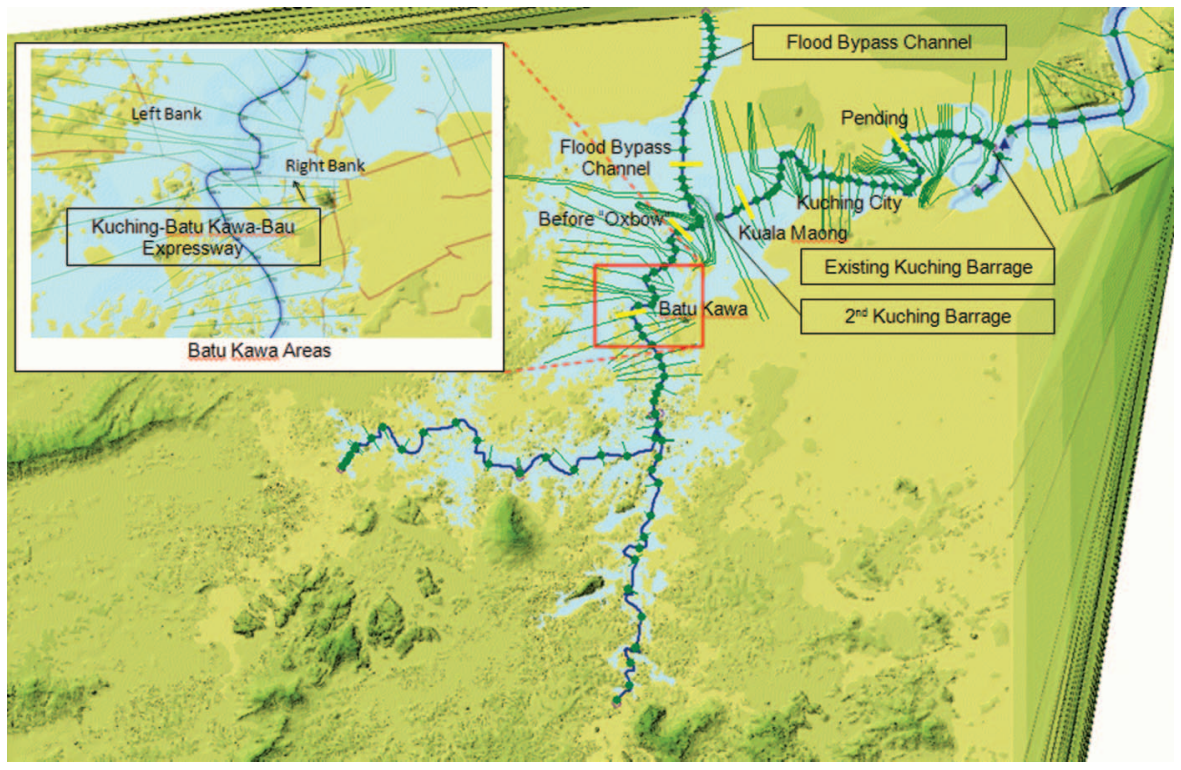

Figure 7. Simulation of January 2004 flood event with flood bypass channel.

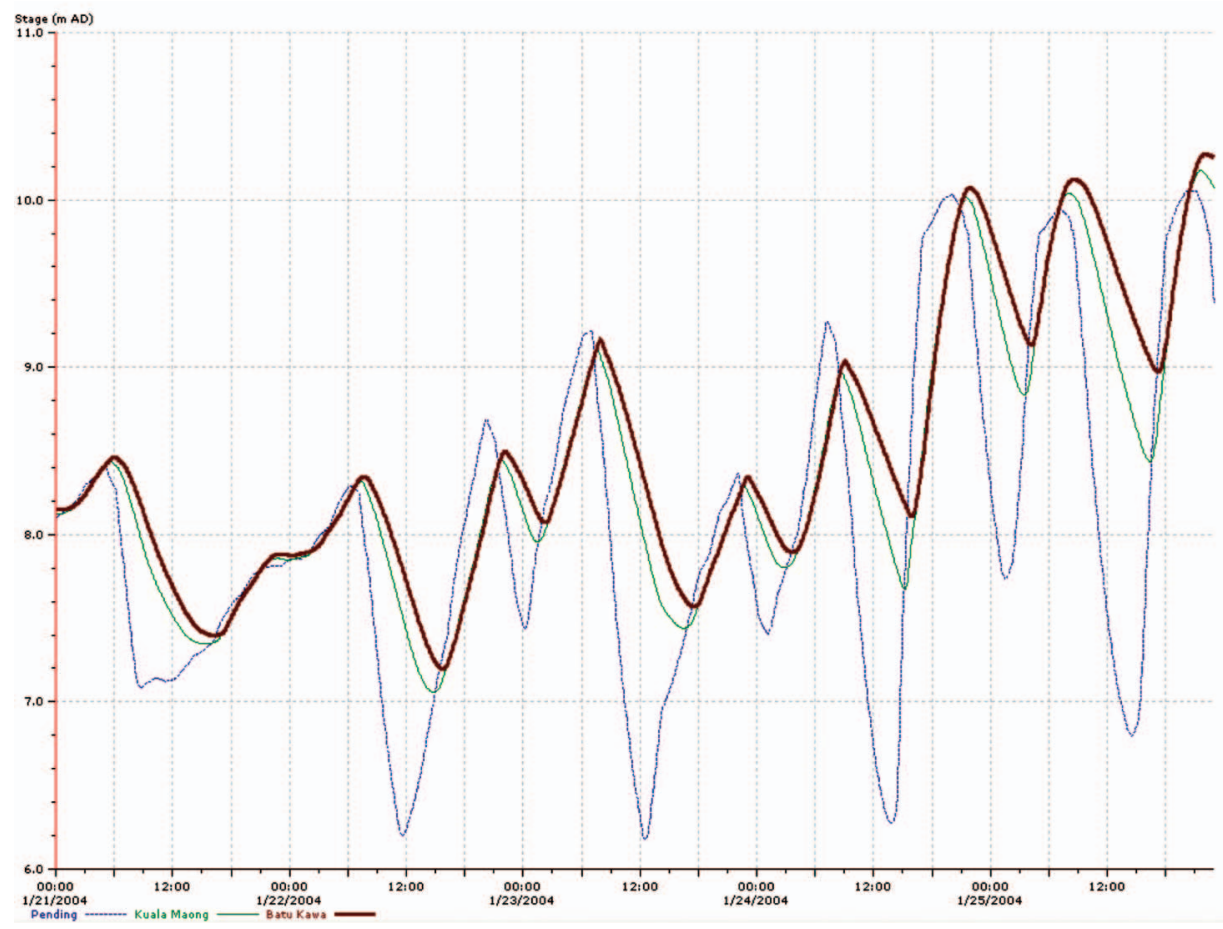

Figure 8. Simulated water level hydrographs of January 2004 flood event for existing Sarawak River conditions.

astronomical tides collision were run through the model incorporated bypass channel. So Figure 9 is divided into two parts. While the 100-year flood flows were to be diverted by the bypass, the Lower Sarawak River was predominantly tidal as shown in the water level hydrographs of Pending and Kuala Maong (see
Figure 9(a)). This explains the flooding of the Lower Sarawak River which persisted in Figure 7.

On the other hand, the Upper Sarawak River was acted on solely by the upstream flows. The water levels were lower as floodwaters travel downstream from Batu Kawa to flood bypass channel (see Figure 9(b)). Note 


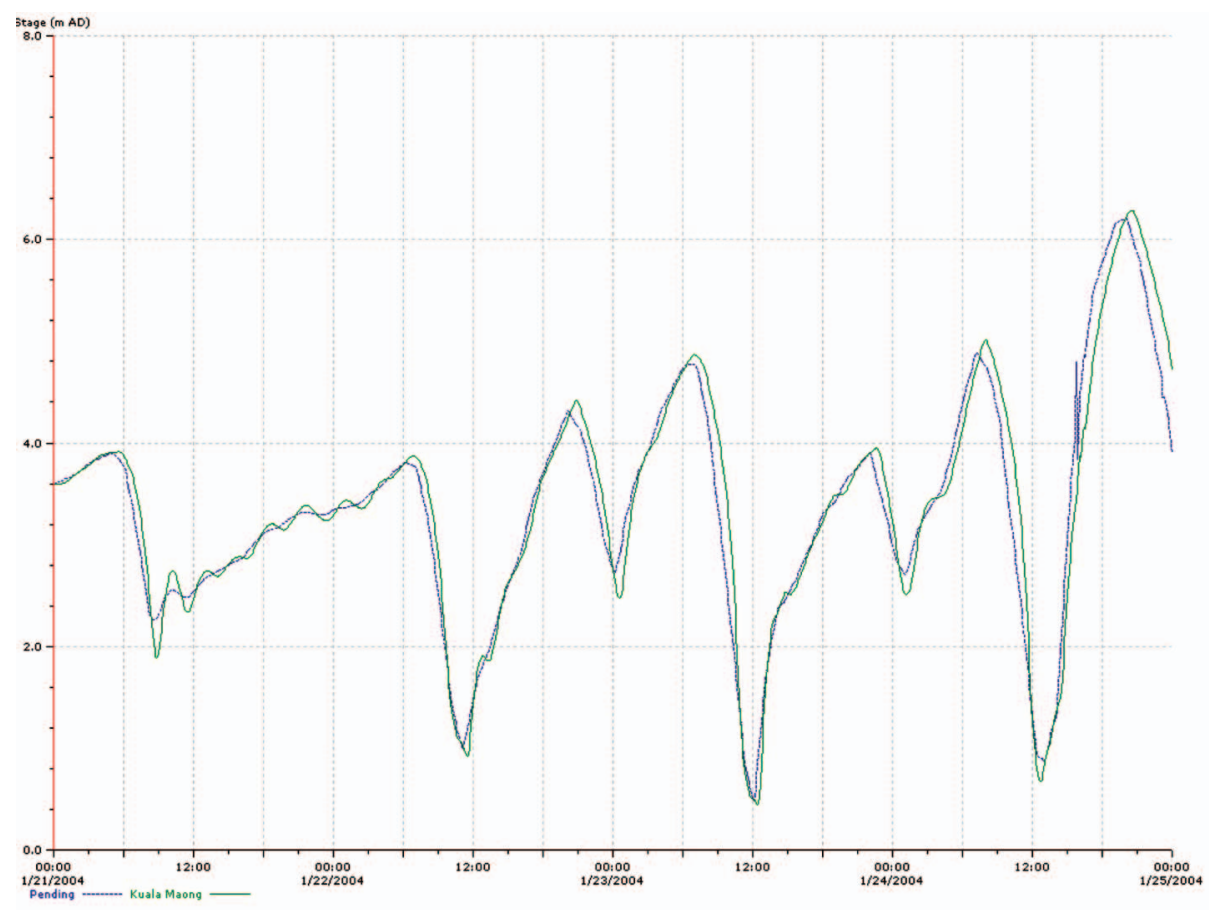

(a)

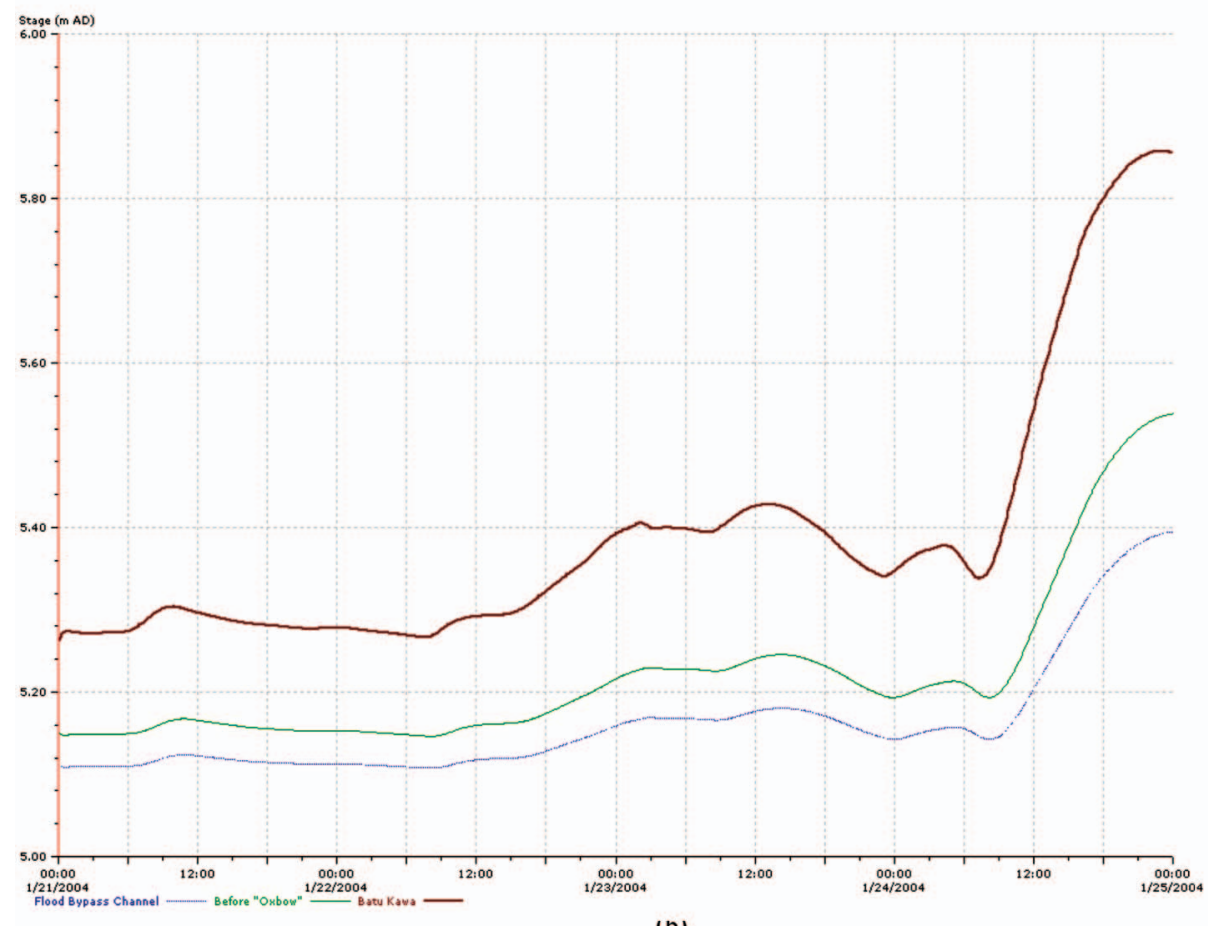

(b)

Figure 9. Simulated water level hydrographs of January 2004 flood event for Sarawak River with flood bypass channel, (a) Lower Sarawak River, and (b) Upper Sarawak River.

that the mentioned locations are marked in Figure 7. The model had dictated that the volume of floodwater was 397 million $\mathrm{m}^{3}$ before the 'oxbow', and 392 million $\mathrm{m}^{3}$ entering the flood bypass channel. However, the floodwaters would form a pool before the bypass channel as shown in Figure 7. The bypass channel is to be installed with flood gates allowing one way flow, therefore tidal action is not modelled in this case. 


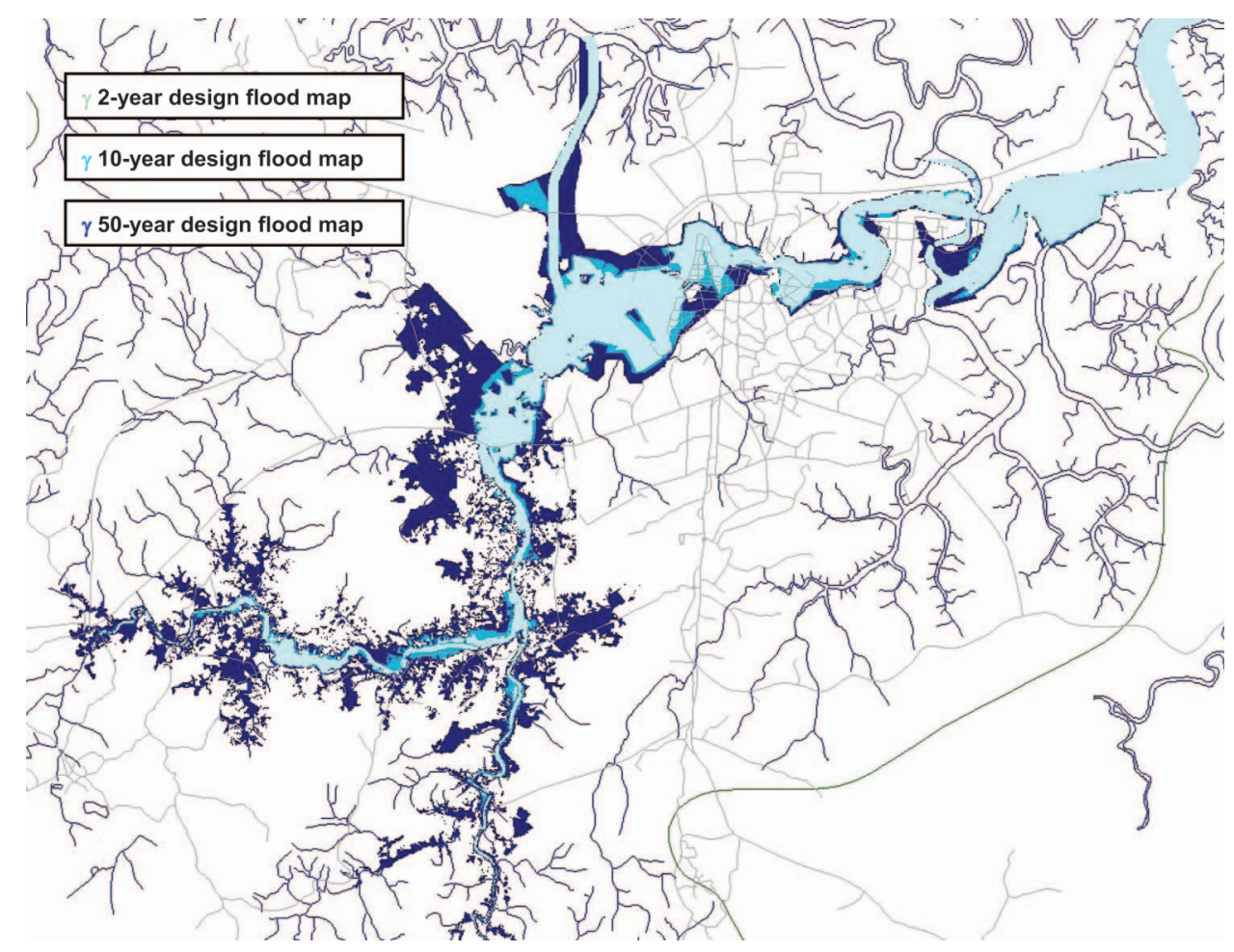

Figure 10. Simulated 2, 10 and 50 year design floods for Sarawak River with flood bypass channel.

Table 1. Estimated length of Kuching-Batu Kawa-Bau Expressway affected by floodwater with and without flood bypass channel.

\begin{tabular}{lccl}
\hline & \multicolumn{2}{c}{ Affected length of road (km) } & \\
\cline { 2 - 3 } Event & $\begin{array}{c}\text { Without flood } \\
\text { bypass channel }\end{array}$ & $\begin{array}{c}\text { With flood } \\
\text { bypass channel }\end{array}$ & Remarks \\
\hline $\begin{array}{c}\text { 2-year design } \\
\text { flood }\end{array}$ & 1.4 & 1.4 & - \\
$\begin{array}{c}10 \text {-year design } \\
\text { flood }\end{array}$ & 3.3 & 1.4 & $-57 \%$ \\
$\begin{array}{c}50 \text {-year design } \\
\text { flood }\end{array}$ & 5.9 & 2.7 & $-54 \%$ \\
$\begin{array}{c}\text { January 2004 } \\
\text { flood }\end{array}$ & 10.2 & 4.8 & $-53 \%$ \\
\hline
\end{tabular}

The 2, 10 and 50-year design flood flows were also run through the developed river model showing the impact that the flood bypass channel would have. The resulting flood maps in Figure 10 show that flooding problems persisted in Batu Kawa areas even for a small flood event of a 2-year return period. This means the bypass channel would lessen the flooding but not totally eliminate them. A summary of the affected length of Kuching-Batu Kawa-Bau Expressway with and without a bypass channel is tabulated in Table 1 . The statistics show a reduction of road length affected by flooding in all modelled events. The modelling result had indicated that the bypass channel would help to reduce $53 \%$ of the road from flooding. Similarly, the modelling of the design floods had predicted $54-57 \%$ reduction of road inundation.

\section{Conclusions}

Sarawak River basin is generally quoted as $1430 \mathrm{~km}^{2}$ in size and only $6 \%$ of the area is developed (Memon and Murtedza 1999). Nevertheless, the catchment size is enormous and the flood runoff generated can be equally huge. The modelling efforts of the January 2004 historical flood and 2, 10, 50-year design floods had predicted Batu Kawa to remain flood-prone even with a flood bypass channel in place. In other words, Batu Kawa is a natural flood plain. With that in mind, the estimation of reduction of flooded road length is very positive considering the difficulty in fighting the power of nature. An average reduction of $55 \%$ on the flooding of Kuching-Batu Kawa-Bau Expressway would be attained when floodwaters were bypassed. One may argue for an increase in the conveyance capacity of the bypass channel, but the acquisition of lands and deeper earthworks would only inflict greater cost. It may need further consideration.

It would not be practical to remove or re-route a major road like the Kuching-Batu Kawa-Bau Expressway. The modelling results would still be useful in the 
context of upgrading and maintaining the road. The road authorities would know, for example, to what level they should heighten the road or which stretch of road should be prioritised. A computer model is always a powerful tool to show "what would be happening' and then assist decision making.

\section{Acknowledgements}

The authors would like to acknowledge two blog sites, ahbau.net and www.petfrd.com from where the photos depicted in Figure 3 were extracted. This paper is part of the 'Flow Resistance and Discharge Estimation for Flooding River' project funded by the Malaysian Ministry of Science, Technology and Innovation (MOSTI) under Science Fund (Grant number 04-01-05-SF0415).

\section{References}

Benito, G., Lang, M., Barriendos, M., Llasat, M.C., Frances, F., Ouarda, T., Thorndycraft, V.R., Enzel, Y., Bardossy, A., Coeur, D. and Bobee, B., 2004. Use of systematic, palaeoflood and historical data for the improvement of flood risk estimation. Review of scientific methods. Natural Hazards, 31 (3), 623-643.

Department of Irrigation and Drainage (DID) Sarawak, 2004. Flood report of Kuching and Samarahan divisions.

Furniss, M.J., Love, M.A., and Flanagan, S.A., 1997. Diversion potential at road-stream crossings. United States Department of Agriculture, Document 9777 1814SDTDC, December.

Furniss, M.J., Ledwith, T.S., Love, M.A., McFadin, B.C., and Flanagan, S.A., 1998. Response of road-stream crossings to large flood events in Washington, Oregon and Northern California. United States Department of Agriculture, Document 9877 1806-SDTDC, September.

Hey, R.D., 1990. Environmental river engineering. Water and Environment Journal, 4 (4), 335-340.

Horritt, M.S. and Bates, P.D., 2002. Evaluation of 1D and 2D numerical models for predicting river flood inundation. Journal of Hydrology, 268, 87-99.

Jurutera Jasa Consultanting Engineers, 2003. Sungai Sarawak flood mitigation options study. Final Report for the State Government of Sarawak, Malaysia, February.

Jurutera Jasa Consulting Engineers, 2006. The proposed flood mitigation design options for Batu Kitang and Batu Kawa urban centres along Sg. Sarawak, Kuching, Sarawak. Final Report for the State Government of Sarawak, Malaysia, April.
Jenny, K.K., Mah, D.Y.S., Putuhena, F.J., and Salim, S., 2007. Post-flood forensic analysis of Sungai Maong using InfoWorks River Simulation (RS). Journal of the Institution of Engineers, Malaysia (IEM), 68 (4 December), 41-46.

Narrabri Shire Council (New South Wales, Australia), 2007. The Narrabri Flood Bypass Feasibility Study. February.

Mah, D.Y.S., Putuhena, F.J., and Salim, S., 2007. Use of InfoWorks River Simulation (RS) in Sungai Sarawak Kanan modelling. Journal of the Institution of Engineers, Malaysia (IEM), 68 (1 March), 1-10.

Mark, O., Weesakul, S., Apirumanekul, C., Aroonnet, S.B., and Djordjević, S., 2004. Potential and limitation of 1D modelling of urban flooding. Journal of Hydrology, 299, 284-299.

Memon, A. and Murtedza, M., 1999. Water resources management in Sarawak, Malaysia. Kuching: Universiti Malaysia Sarawak.

Salim, S., Mah, D.Y.S., Sumok, P., and Lai, S.H., 2009. Water quality monitoring of Maong River, Malaysia. Water Management. Proceedings of the Institution of Civil Engineers (UK), 162 (1), 37-42.

Santos, J.M., Ferreira, M.T., Godinho, F.N., and Bochechas, J., 2005. Efficacy of a nature-like bypass channel in a Portuguese lowland river. Journal of Applied Ichthyology, 21 (5), 381-388.

Satellite Imageries of Kuching City, Sarawak, extracted from Wikimapia [online]. Available from: http://www. wikimapia.org [Accessed January 2009].

Sommer, T., Harrell, B., Nobriga, M., Brown, R., Moyle, P., Kimmerer, W., and Schemel, L., 2001. California's Yolo bypass: Evidence that flood control can be compatible with fisheries, wetlands, wildlife, and agriculture. Fisheries, 26, 6-16.

Wallingford Software, 2006. Floodplain analysis and development of a flood risk map for Malaysia's Selangor River basin. User case studies [online]. Available from: http://www.wallingfordsoftware.com/casestudies/ fullarticle.asp?ID=574 [Accessed 6 November 2009].

Wallingford Software, 2008a. Modelling the Tabasco floods. User case studies [online]. Available at http://www. wallingfordsoftware.com/casestudies/fullarticle.asp? ID =846 [Accessed 6 November 2009].

Wallingford Software, 2008b. Manual for InfoWorks RS Version 9.5 .

Wallingford Software, 2009. InfoWorks RS forms basis for flood map of Northern Ireland. User Case Studies [online]. Available from: http://www.wallingfordsoftware.com/casestudies/fullarticle.asp?ID $=870 \quad$ [Accessed November 2009]. 